\title{
Evaluation of a proposed technique to assess unscheduled DNA synthesis and genotoxicity
}

\author{
R A Goodlad, C Y Lee, M R Alison, C E Sarraf, M A Ghatei, S R Bloom, N A Wright
}

\begin{abstract}
Results from a recent, new assay suggest that omeprazole, a potent inhibitor of gastric acid secretion, is genotoxic. The principle of this assay is that the non-proliferating zone of surface gastric epithelial cells can be selectively removed by controlled digestion so that any incorporation of tritiated thymidine into these cells represents unscheduled DNA synthesis. Parietal cells (which are located below the uppermost proliferating cells) and proliferating cells in semiconservative, regular DNA synthesis could always be shown in the digested fraction, and as regular DNA synthesis takes up a thousand fold more thymidine than unscheduled DNA synthesis, any signal from unscheduled synthesis would therefore be swamped. The digestion process was also uneven, as histological analysis showed denuded patches of mucosa, and gland like structures were seen in the digest. Quantification of the number of silver grains over the nuclei showed no increase in low level labelling after omeprazole administration, indicating that there was no unscheduled DNA synthesis. The labelling index of undigested gastric tissue from omeprazole treated rats was not significantly different from that of the control group, despite an increase in the plasma gastrin value.

(Gut 1993; 34: 235-241)
\end{abstract}

Carcinogenesis is a multistage process involving permanent changes in DNA.' DNA repair can occur after genotoxic damage as 'unscheduled DNA synthesis', and mis- or incomplete DNA repair may be related to carcinogenesis. While there are several well established tests for genotoxicity, ${ }^{23}$ these are either in vitro assays or use non-gastrointestinal tissue systems, thus a new in vivo test could have considerable potential. Such genotoxicity assay for the rat stomach has recently been described by Burlinson, ${ }^{+}$who reported that the powerful proton pump inhibitor, omeprazole, ${ }^{56}$ stimulates unscheduled DNA synthesis. ${ }^{7}$ Other anti-acid drugs, namely loxtidine, cimetidine, and ranitidine did not have this effect. ${ }^{8}$ These findings have considerable implications ${ }^{9}$ but are at variance with the data generated from the extensive application of established genotoxicity methods." The site specific mode of action of omeprazole, in which the active form (sulphenamide) is generated only in the cannuliculi of the parietal cells has led to the value of these data being questioned."

The basis of the Burlinson technique is that non-proliferating gastric surface epithelium cells are selectively removed by enzymatic digestion in vitro, the test agents having been previously administered in vivo. Detection of tritiated thymidine in the cell digests should then be proportional to the amount of unscheduled DNA synthesis. The validation of such a technique is a matter of some importance. If unscheduled DNA synthesis activity is used as a means of detecting genotoxic events, it is vitally important that it is distinguished from semiconservative, schedule, regular DNA synthesis as the uptake of tritiated thymidine during regular DNA synthesis is much greater than that during unscheduled DNA synthesis. Differentiation of unscheduled DNA synthesis from regular DNA synthesis accompanying cell division in the gastric mucosa is technically difficult. While regular DNA synthesis is maximal around the isthmus neck junction of the gastric glands, it is detectable up to five cell positions from the surface. Any method that relies on selective separation of non-dividing surface cells to identify unscheduled DNA synthesis requires stringent controls to exclude contamination with deeper dividing cells. This is particularly important in situations where there is a stimulus to cell proliferation, when cells undergoing regular DNA synthesis may be seen closer to the surface.

\section{Methods}

EXPERIMENTAL DESIGN

The first part of the study investigated the effects of vehicle, pure omeprazole $(60 \mathrm{mg} / \mathrm{kg})$ and the carcinogen MNNG on the specific activity of the cell digests, and on the types of cells present in the digests. There were five animals per group; the stomach rinse from two rats was flushed into $10 \mathrm{ml}$ of $2 \mathrm{X}$ formalin, while that from three rats was prepared for DNA assay.

The second part of the study examined the effects of vehicle, homogenised enteric coated granules of omeprazole ( $30 \mathrm{mg} / \mathrm{kg}$ omeprazole), and MNNG on the specific activity of the cell digests and on the types of cells present in the digests. There were four animals per group. The flushed material was vortexed, $1 \mathrm{ml}$ was spun down and the pellet fixed for histology, while the remaining $9 \mathrm{ml}$ were used for the DNA assay.

In the third part of the study, groups of four rats were gavaged as above, and similar groups were also given hydroxyurea 1 hour before the injection of tritiated thymidine. The stomachs were fixed without protease digestion, further control and omeprazole gavaged groups (three per group) were subjected to the pronase digestion, and half the stomach was fixed for scanning electron microscopy and half for light microscopy. The tritiated thymidine uptake per cell was also determined, as was the grain count, as 
cells with a grain count of 10 or less could be among those undergoing unscheduled DNA synthesis. ${ }^{12}$ These counts were performed on all the gastric cells ( 50 nuclei per animal), and on non-proliferating surface cells (500 nuclei per rat).

ASSAY

Piebald Virol Glaxo (PVG) rats (Medical Research Council, Mill Hill) were given the various agents by gastric gavage and killed 14 hours later. They were injected with $0.5 \mathrm{mCi} / \mathrm{kg}$ of methyl- ${ }^{3} \mathrm{H}$-Thymidine $(37 \mathrm{MBq} / \mathrm{ml}$, Amersham, Aylesbury, Buckinghamshire) 1 hour before anaesthesia and exsanguination. The abdomen was opened and the stomach gently removed. The squamous portion of the stomach was trimmed and the remaining stomach washed thoroughly with warm saline. A thin strip of squamous stomach was clamped, the duodenum cannulated with PVC tubing and 1.5 to $2 \mathrm{ml}$ of protease added (Type XXI from Streptomyces griseus, Sigma Chemical Co Ltd, Poole, Dorset; $500 \mathrm{U} / \mathrm{ml}$ in Eagle's medium). The cannula was clamped and the stomach incubated for 40 minutes in Eagle's medium at $37^{\circ} \mathrm{C}$. The clamps were then removed, the stomach rinsed with $10 \mathrm{ml}$ of Eagle's medium, and the washings collected for subsequent assay.

\section{DRUGS}

All agents were made up near the time of administration. Omeprazole was made up in $0.5 \%$ Methocel (hydroxpropyl methylcellulose) with $2 \mathrm{mg} / \mathrm{ml}$ of $\mathrm{NaHCO}_{3}$ and the $\mathrm{pH}$ was adjusted to $9 \cdot 0$. The drug used in the first investigation was pure omeprazole (from $\mathrm{AB}$ Hassel, S-43183 Molndal, Sweden, at a dose of $60 \mathrm{mg} / \mathrm{kg}$ ). In the second and third investigations, enteric coated granules (Losec, AB Hassel) were dispersed in Methocel using a polytron (Northern Media Services, Sainsbury Way, North Humberside) to give an omeprazole concentration of $30 \mathrm{mg} / \mathrm{kg}$. MNNG $(50 \mathrm{mg} / \mathrm{kg}$, Sigma Chemicals, Poole, Dorset) was made up in Methocel.

Hydroxyurea was dissolved in warm saline and $400 \mathrm{mg} / \mathrm{kg}$ were injected intraperitonealy 2 hours before killing.

\section{HISTOLOGY}

All material was fixed in formalin, embedded in paraffin wax, and alternate $4 \mu \mathrm{m}$ sections were cut and mounted. Autoradiographs were prepared by the dipping method using Ilford K2 emulsion (Ilford Ltd, Knutsford, Cheshire). The autoradiographs were exposed for 3 weeks and then developed in Kodak D19b, fixed and stained with haematoxylin. Cells were scored as labelled if there were four or more grains over the nucleus. The gastric fundus was scored using a 63 time oil-immersion objective. A $1 \mathrm{~cm} \times 1 \mathrm{~cm}$ eyepiece graticule was lined up with the muscularis mucosa and all epithelial cells to the luminal side of this were counted. This necessitated moving the graticule grid three or four times. Three such 'supergrids' per rat were scored. All slides were scored 'blind', in that the person reading the slides was unaware of the group to which the slides belonged.

For lectin staining of the parietal cells the sections were dewaxed, endogenous peroxidase activity was blocked, and they were incubated with the lectin peanut agglutin (PNA, Vector Labs, Bretton, Peterborough) at a dilution of 1:200 for 35 minutes. After this the sections were incubated with the avidin-biotin peroxidase complex for 35 minutes, and the colour reaction developed with DAB (3-5 minutes). Nuclei were stained with Mayer's haematoxylin.

\section{BIOCHEMISTRY}

The pronase fraction was spun at $100 \mathrm{~g}$, the supernatant discarded, and $5 \mathrm{ml}$ of $10 \%$ trichloroacetic acid (TCA) were added, followed by $2 \mathrm{ml}$ of $1 \mathrm{M} \mathrm{NaOH}$. The fraction was shaken and $2 \mathrm{ml}$ of $10 \%$ perchloric acid were added, followed by $1 \mathrm{ml}$ of $5 \%$ perchloric acid. The tube was left to precipitate on ice for 15 minutes and was then spun at $750 \mathrm{~g}$ for 10 minutes. The supernatant was discarded and the pellet frozen.

Each pellet was dissolved in $0.5 \mathrm{ml} 1 \mathrm{M} \mathrm{NaOH}$ to which was added $1 \mathrm{ml}$ of TCA-HCl $(15 \%$ TCA in $2 \mathrm{M} \mathrm{HCl}$ ). The mixture was vortexed and left to stand for 15 minutes at $4^{\circ} \mathrm{C}$ before centrifugation at low speed. The supernatant was discarded and the pellet resuspended in TCA- $\mathrm{HCl}$ twice more until all the acid soluble radioactivity was removed (as ascertained by scintillation counting). The final pellet was resuspended in $1 \mathrm{ml} \mathrm{5 \%}$ TCA and heated at $90^{\circ} \mathrm{C}$ for 20 minutes with occasional mixing. The mixture was then centrifuged at $2000 \mathrm{~g}$ for 10 minutes. One $\mathrm{ml}$ of the chromogen solution ( $1 \mathrm{~g}$ diphenylamine in $100 \mathrm{ml}$ glacial acetic acid $+2 \cdot 75 \mathrm{ml}$ concentrated sulphuric acid) was added to $0.5 \mathrm{ml}$ of the clear supernatant. This mixture was immersed in a water bath at $100^{\circ} \mathrm{C}$ for 10 minutes and the resultant absorbance was read at $600 \mathrm{~nm}$ on a Cecil series 2 spectrophotometer (Cecil Instruments, Milton Industrial Estate, Cambridge). DNA standards $(5-100 \mathrm{~g} / \mathrm{ml}$ of calf thymus DNA, Sigma) were treated in a similar manner. Duplicate $0.5 \mathrm{ml}$ aliquots from each reaction mixture were added to $10 \mathrm{ml}$ of scintillation fluid (Instagel; Packard, Pangbourne, Berks) and the radioactivity was measured on a Packard Tricarb 1900 CA scintillation counter with on-board quench correction.

\section{SCANNING ELECTRON MICROSCOPY}

Appropriate samples (approximately $0.5 \mathrm{~cm}$ in diameter) from three vehicle and three omeprazole (granule) treated rats were taken with maximal care to avoid physical damage to the surface of the stomachs. All tissues were fixed in $2 \%$ gluteraldehyde in phosphate buffer (EM grade) for 2-3 hours followed by several rinses in sucrose/phosphate buffer. Tissues were osmicated, rinsed, and dehydrated in a series of graded acetone's followed by critical point drying and sputter coating with gold. Stomachs were then viewed on a Cambridge Stereoscan 360 scanning electron microscope. 
Figure 1: The effects of the various treatments on the DNA specific activity of the protease digests in the first and the second investigations.
Figure 2: Photomicrograph of the cells washed out of the rat stomach after 40 minutes protease digestion and stained with haematoxylin and eosin. Note the variety of fragments and cell types. The larger, paler cells are parietal cells. (Bar $=100$ um.)

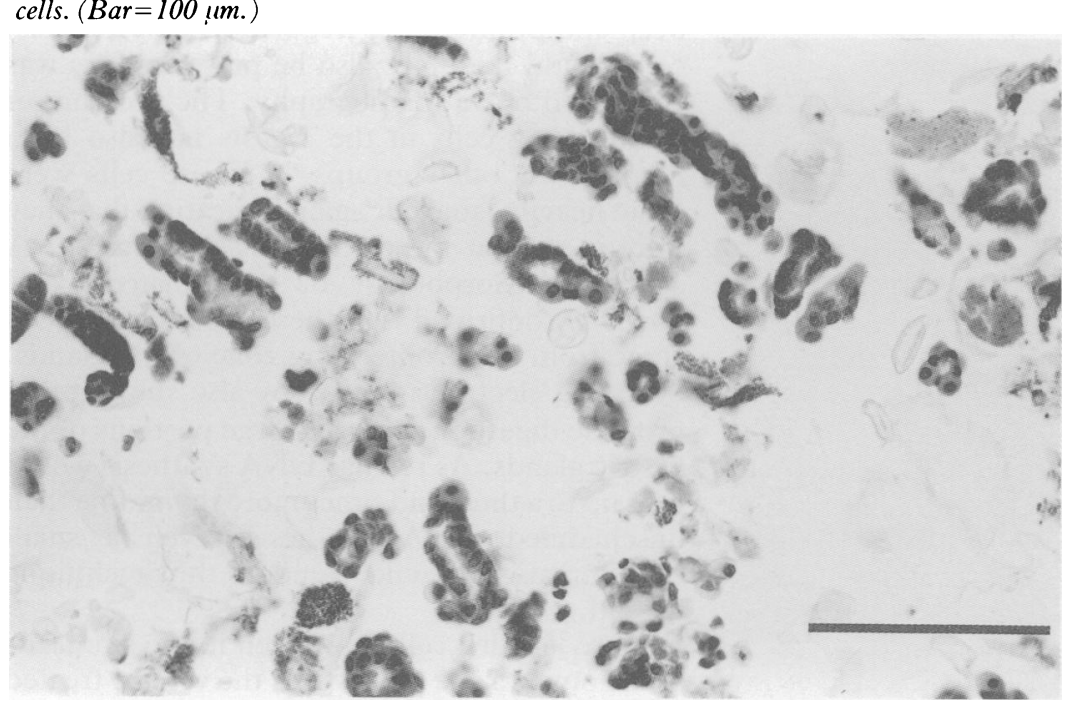

STATISTICS

All results are presented as the mean (SEM). Data were tested by a two sided $t$ test.

The distribution of the labelling grain count was tested to determine whether the data were compatible with the normal distribution by plotting and correlating the cumulative frequency distribution of the data against the cumulative frequency distribution of the normal distribution. ${ }^{16}$

\section{Results}

The carcinogen MNNG increased the specific activity of the protease digests in both studies but there was considerable intra-animal variation (Fig 1). While omeprazole seemed to increase activity in the first study (where the pure drug was used), the difference was not statistically significant. There was no indication of any such effect in the second investigation, where homogenised granules were used

The preservation of the cell digests was better in the first investigation, where the cells were washed into formalin, but there was less recovery of material in the centrifuge pellets. All digests contained a variety of cell types, including parietal cells (Fig 2), which was confirmed by their lectin staining. Proliferating mucous neck cells were also seen (Fig 3). There were more labelled cells in the digest from the omeprazule group $(4.5(0.2) \%$ v $2.6(0.5) \%, \mathrm{p}<0.05$ (second investigation)). The percentage of labelled cells in the digest from the MNNG treated rats was $10 \cdot 1(1 \cdot 3) \%$, which was significantly greater $(\mathrm{p}<0.01)$ than that of the vehicle.

In addition, tubes of cells closely resembling
HORMONE ASSAYS

Gut hormones were measured by previously described radioimmunoassays for enteroglucagon, ${ }^{13}$ peptide $\mathrm{YY},{ }^{1+}$ and gastrin. ${ }^{15}$ Enteroglucagon was calculated by subtracting specifically measured pancreatic glucagon (C-terminal immunoreactivity measured with the antiserum RCS5 from total N-terminal glucagon immunoreactivity (measured with antiserum R59)). The assays were capable of detecting, pancreatic glucagon $2 \mathrm{pmol} / \mathrm{l}$, enteroglucagon $5 \mathrm{pmol} / \mathrm{l}$, peptide YY $2 \cdot 5 \mathrm{pmol} / \mathrm{l}$, and gastrin $2 \mathrm{pmol} / \mathrm{l}$ with $95 \%$ confidence. the gastric neck or isthmus were often seen (Fig 4). Areas of denuded mucosa were seen in the remaining stomach tissue, especially of the MNNG treated group. Scanning electron microscopy of specimens that had undergone protease digestion showed damage to the surface of the stomach that invariably included detachment of large sections of the gastric glands (Fig 5).

Omeprazole had little effect on the labelling index of undigested tissue while MNNG had a large effect (Fig 6). The cell population seemed to be slightly decreased by hydroxyurea $(\mathrm{p}=0.086)$. Hydroxyurea reduced labelling by $100 \%$ in the vehicle group and by $95 \%$ in the omeprazole group. However, the inhibition of proliferation by hydroxyurea in the MNNG treated group was only $54 \%$.

Grain count analysis showed that there was no significant difference in the mean number of grains per nucleus in the vehicle treated and in the omeprazole treated rats $(61 \cdot 7(6 \cdot 2) v 57 \cdot 28$ $(1 \cdot 0))$. There were slightly more grains in the MNNG treated $(66 \cdot 1)(5 \cdot 34)$ animals. Normal scores tests showed that the distribution of the grain count in both groups was compatible with the normal distribution $(p<0 \cdot 05)$. Analysis of all the surface cells showed no difference in the number of lightly labelled cells between the omeprazole and the vehicle treated groups.

Omeprazole increased the plasma gastrin in all parts of this study but the pure form of the drug was less effective than the homogenised granules used in the second and third investigations 


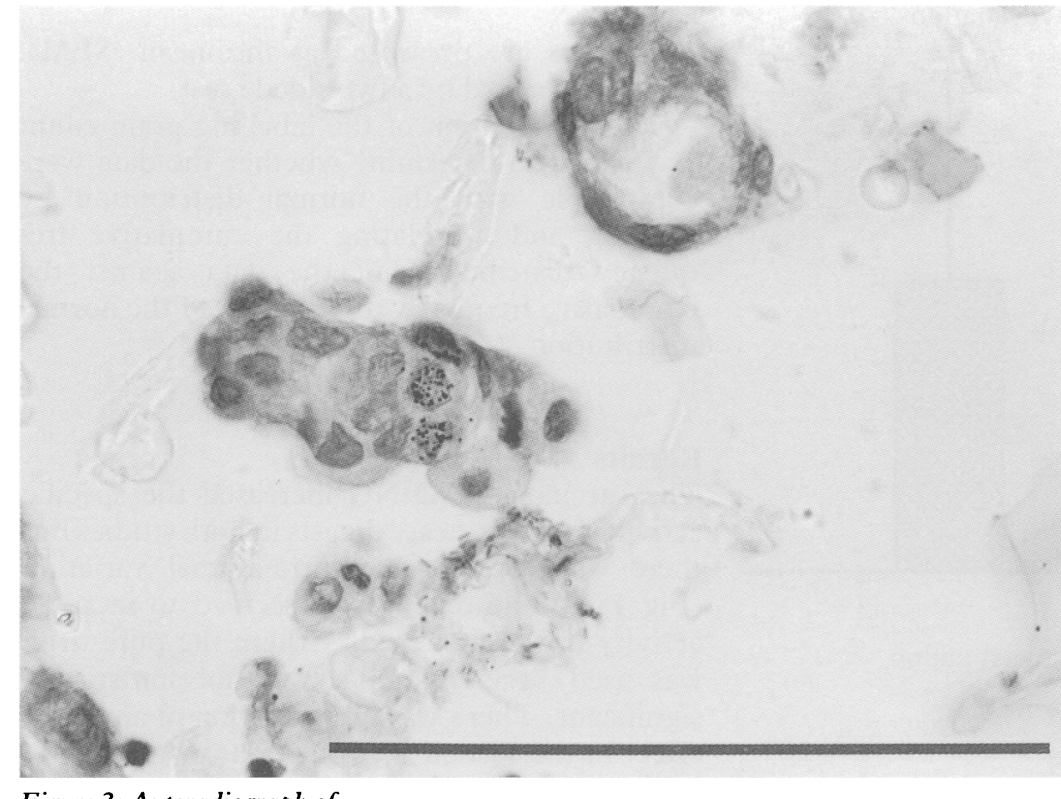

Figure 3: Autoradiograph of cells washed out of the rat stomach after 40 minutes protease digestion. Thymidine uptake is indicated by the black silver grains overlying the nucleus. $($ Bar $=100 \mu \mathrm{m}$.)
(Fig 7). MNNG reduced gastrin in the first and second investigations, and decreased plasma peptide YY levels in the third investigation. Hydroxyurea had no effect on gastrin or peptide YY, but significantly increased plasma enteroglucagon.

\section{Discussion}

While omeprazole seemed to increase specific activity in the digests of the first study, in which $60 \mathrm{mg} / \mathrm{kg}$ of the pure drug was used, the difference was not statistically significant. There was no indication of such an effect in the second investigation, in which homogenised granules were used. This was despite the greater effect of the granule form on plasma gastrin. The
Figure 4: Photomicrograph of tube like structures seen in the pronase digests, these closely resembled the neck or isthmus portion of the gastric gland. $($ Bar $=100 \mu \mathrm{m}$.) different doses were used as it had been stated that dispersed granules were more effective. ${ }^{17}$ Presumably these differences reflect the relatively instability of the pure form of the drug, especially as omeprazole is a pro-drug, converted to its active form by the acid in the parietal cells. ${ }^{18}$ While the use of the drug in this form increased plasma gastrin, the time course of this is not known, thus it is possible that the effect of the drug is delayed by this formulation. These differences in formulation make comparisons with other acid inhibitors, which have a shorter duration of action, rather difficult. ${ }^{19}$

The feedback between acid inhibition and gastrin levels is well known but even here there can be some surprises. ${ }^{2021}$ While there is little evidence of a proliferative effect of gastrin throughout the gut, a proliferative role for gastrin in gastric hyperplasia, and especially endocrine cell growth, is well established. ${ }^{22}$ The data on the proliferative effects of omeprazole are contradictory. In normal ${ }^{23}$ and antrectomised rats, ${ }^{24}$ omeprazole had no effect on gastric proliferation, supporting the conclusion that acid inhibiting, drug induced hyperplasia is mediated via gastrin ${ }^{25}$; nonetheless, proliferative responses have recently been reported. ${ }^{26}{ }^{27}$ Lifelong gastrin induced enterochromaffin like cell hyperplasia ${ }^{28}$ in experimental animals can lead to low malignancy, non-metastasising carcinoid tumours. ${ }^{29}$ However, rats may be particularly prone to these, ${ }^{5}$ and carcinoids are relatively rare in patients with the massive hypergastrinaemia associated with the Zollinger-Ellison syndrome and pernicious anaemia. ${ }^{30}$ Appreciable trophic effects in omeprazole treated patients were not seen on biopsy. ${ }^{31-33}$ However, some hyperplastic lesions of endocrine cells were observed in a different study ${ }^{3+}$ perhaps associated with higher dose regimens. ${ }^{28}$ While $M N N G$ was shown to have a major proliferative effect in the last investigation, omeprazole did not, despite the rise in gastrin. A possible explanation of the present results is that proliferation may not have been increased at the single time point studied, as rat enterochromaffin-like cells may take some time to show a proliferative response to achlorhydria..$^{35}$

Parietal cells were seen in the digests, and replicating cells are located above the last parietal cell, ${ }^{36}$ thus the pronase digestion had gone too deep and proliferating (regular DNA synthesis) cells would therefore also be present. This was confirmed by autoradiography. The presence of proliferating cells in the digests has also been reported by other groups. ${ }^{37}{ }^{38}$ These cells were quite heavily labelled, again indicating that they were in regular rather than unscheduled DNA synthesis. Morphology of the isolated gland portions confirmed that these cells have indeed come from the proliferating zone of the glands. Scanning electron microscopy also showed that protease digestion removed large portions of the gastric glands. As regular DNA synthesis would take up to a thousand times more thymidine than unscheduled DNA synthesis, even a small contamination would render the technique invalid.

More labelled cells were seen in the stomachs of the omeprazole group than the vehicle treated 

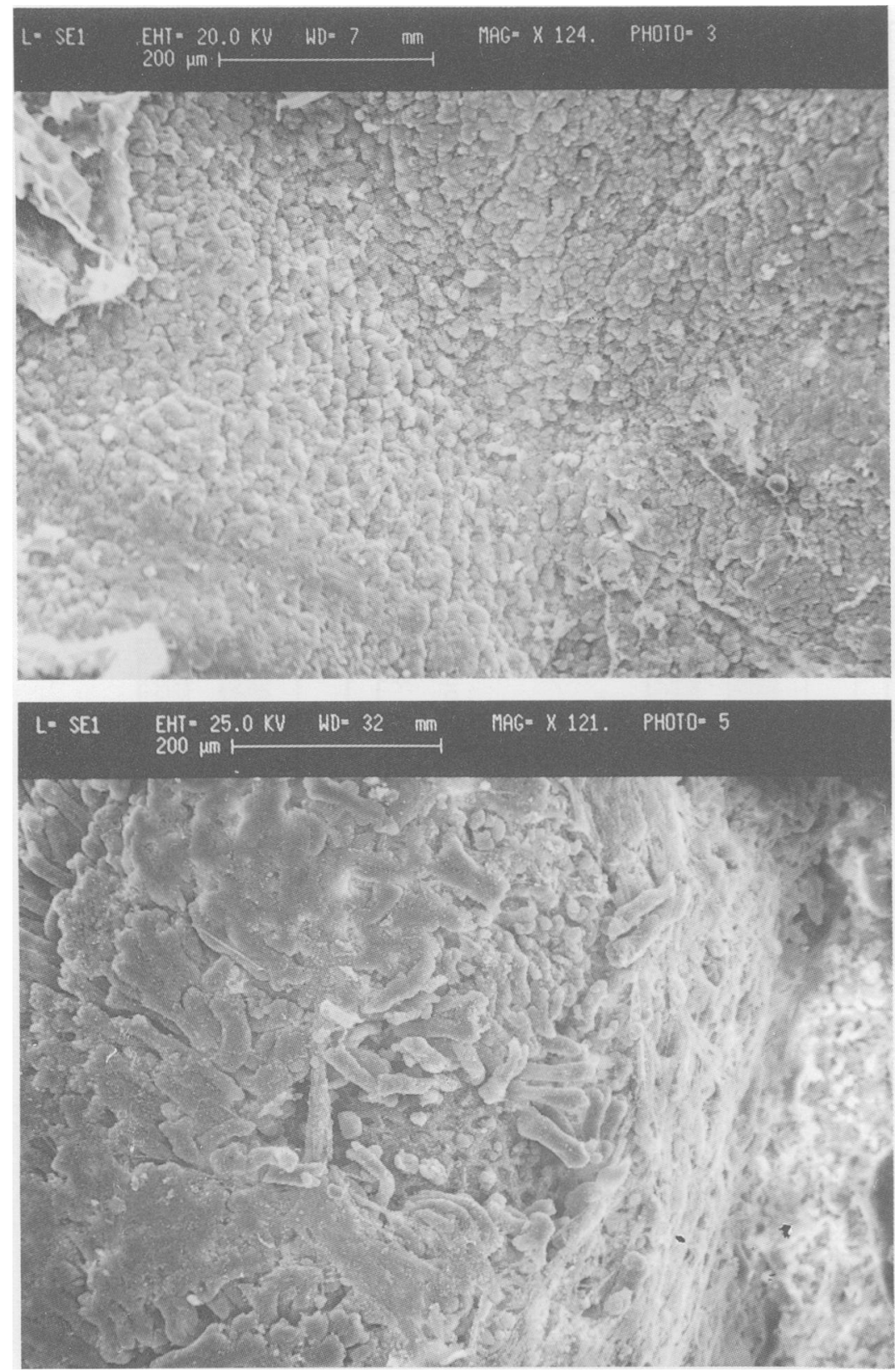

Figure 5: Scanning electron microscopy of (top) control (not incubated) and (bottom) protease digested stomachs (untreated and omeprazole treated) showing damage to the surface of the stomach that included detachment of large portions of the gastric glands.

group, and yet more in the MNNG. In addition, higher labelling indices were seen in the digests of the omeprazole and MNNG treated rats, which suggests that either that the digestion went deeper in these groups or that the proliferative zone was located higher up the gland.

The first investigation seemed to confirm the increase in specific activity of the digests after omeprazole but this did not occur in the second investigation. Other groups ${ }^{37} 39+0$ have also failed to reproduce the 'genotoxic' effect of omeprazole, despite noting an increase in thymidine activity with MNNG.

Some of the conflicting data now emerging in the published reports can be attributed to the strain of rat used-with F344 and PVG rats showing the 'genotoxic effect' and SpragueDawley and Wistar having a negative response. '.

This does not apply to the results of this study in which PVG rats were used.

The preponderance of recent papers therefore
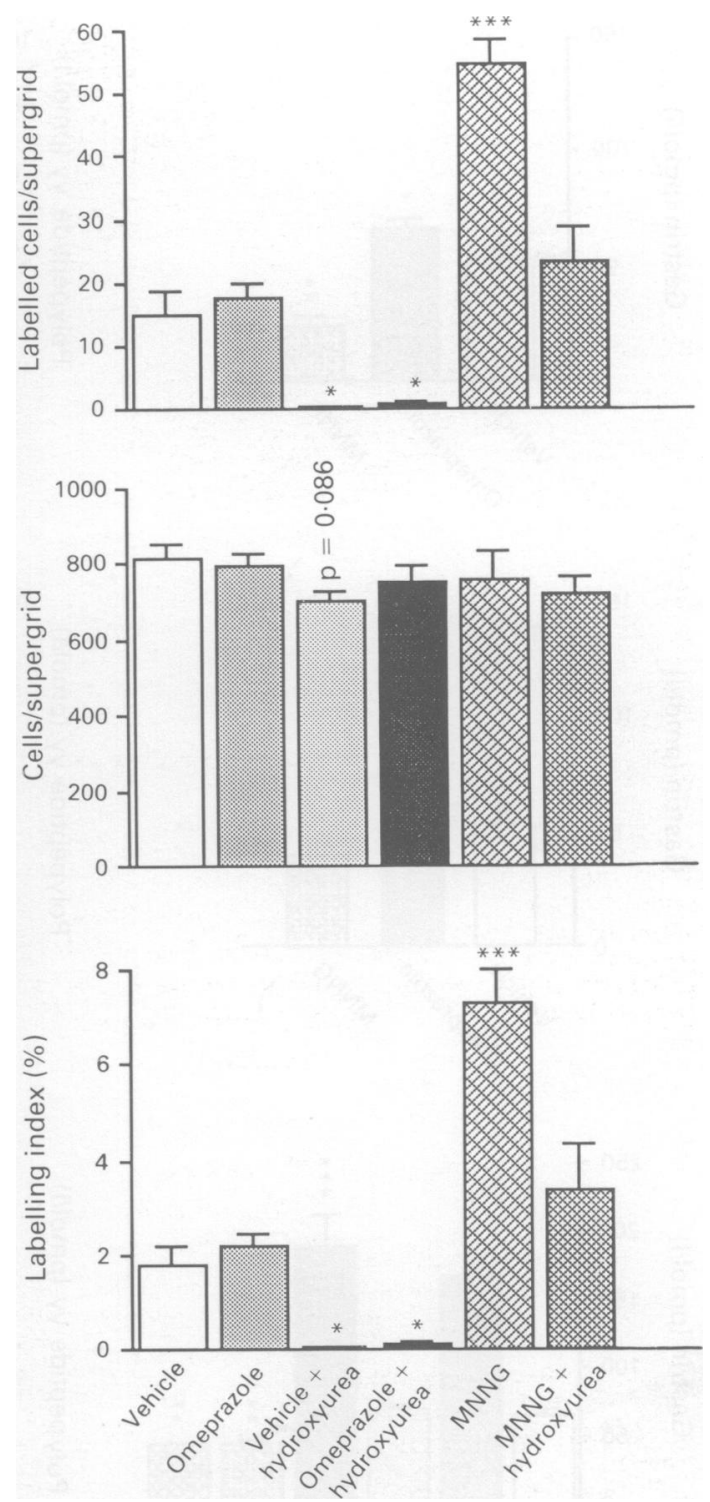

Figure 6: Labelling and cells per 'supergrid' and labelling index of the (unincubated) stomachs. Note the large effect of $M N N G .{ }^{\star}$ Significantly different to the vehicle treated group $(p<0 \cdot 05) ; \star \star$ significantly different to the vehicle treated group $(p<0 \cdot 01) ; \star \star \star$ significantly different to the vehicle treated group $(p<0.001)$.

seem to contradict Burlinson's findings, nonetheless, Furihata et al ${ }^{27}$ reported a dose dependent increase in unscheduled DNA synthesis with omeprazole after blocking regular DNA synthesis with hydroxyurea. However, the small increase in activity in the hydroxyurea treated groups, if added to the non-hydroxyurea treated would not be detectable, thus the contention that omeprazole had no effect on regular DNA synthesis cannot be made.

Hydroxyurea reduced labelling by $100 \%$ in the vehicle group, and by $95 \%$ in the omeprazole group. This agrees with the levels of inhibition expected, ${ }^{39}$ but the effect of hydroxyurea on the MNNG treated group was far less. This illustrates the problems associated with the use of hydroxyurea, as it is difficult to completely abolish regular DNA synthesis, especially after a major proliferative stimulus and raises the question of whether MNNG is necessarily the best (or even a good) choice of a positive control, as like most carcinogens it is a potent 

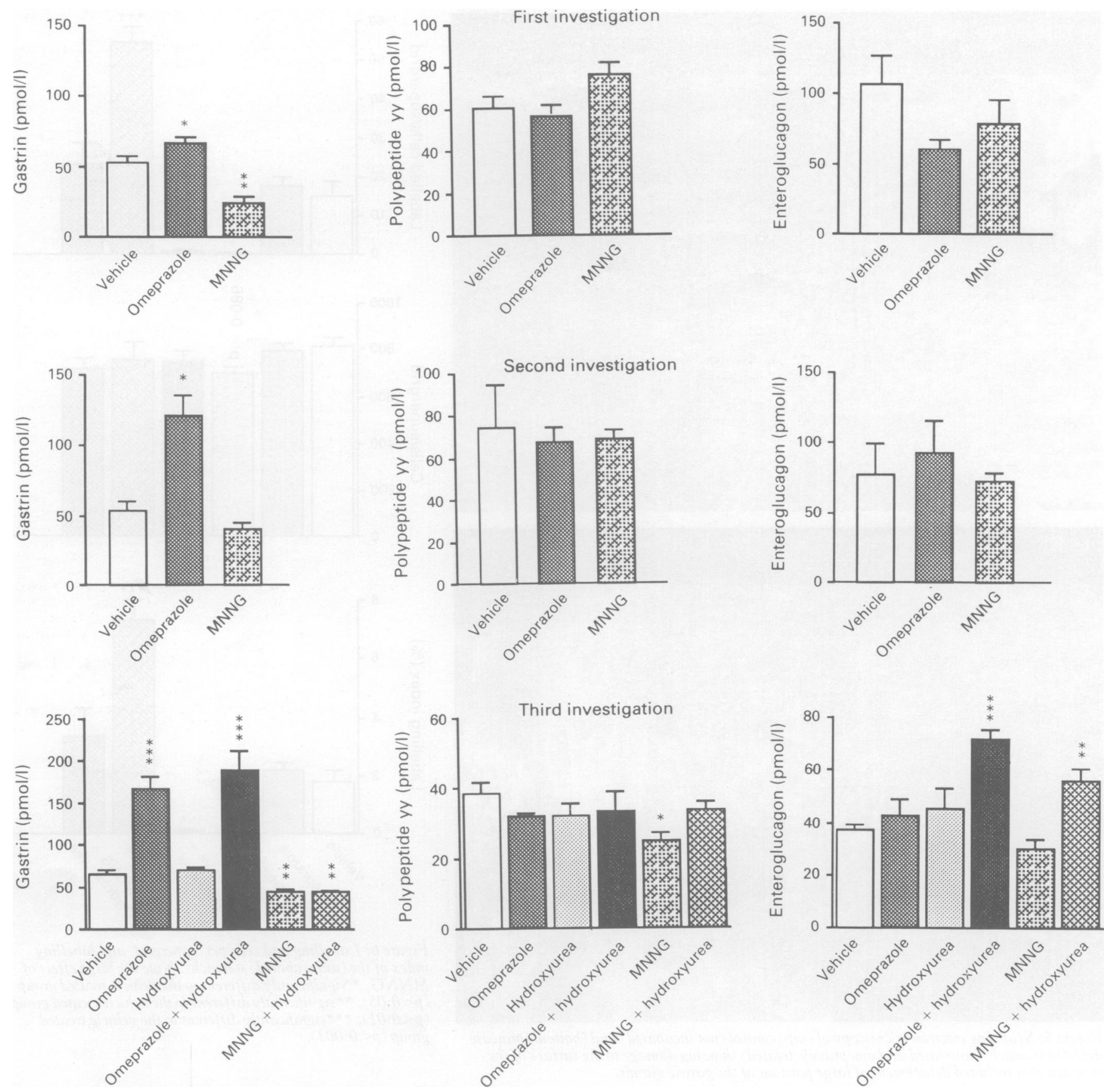

Figure 7: The effects of the various treatments on plasma levels of gastrin, peptide $Y Y$, and enteroglucagon. ${ }^{\star}$ Significantly different to the vehicle treated group $(p<0 \cdot 05) ; \star \star$ significantly different to the vehicle treated group $(p<0 \cdot 01) ; \star \star \star$ significantly different to the vehicle treated group $(p<0 \cdot 001)$.

stimulator of cell proliferation. The results of this study also show that the proliferative response of the stomach to MNNG would be more than enough to explain the increase in specific activity in the pronase digests.

The conclusions of this study are that the assay is without foundation as it does not selectively remove surface cells, and any unscheduled DNA synthesis synthesis would therefore be overwhelmed by contamination with cells regular DNA synthesis. In addition, grain count analysis does not support the contention that omeprazole induces unscheduled DNA synthesis in the rat stomach. Furthermore, the results of the present study do not show any significant effect of omeprazole on gastric proliferation, despite a modest increase in plasma gastrin.
Published as an abstract. Goodlad RA, Lee CY, Alison MA, Saraff C \& Wright NA. Genotoxicity, unscheduled DNA synthesis and omeprazole. Gut 1991; 32: A1208.

1 Fearon ER, Vogelstein B. A genetic model for colorectal tumorigenesis. Cell 1990; 61: 759-67.

2 Williams GM. Methods for evaluating chemical genotoxicity. Ann Rev Pharmacol Toxicol 1989; 29: 189-211.

3 Brillinger RL, Nestmann ER, Sigal EA, Swierenga SH. Recommended protocols based on a survey of current practice. Mutat Res $1991 ; 246: 323-30$.

4 Burlinson B. An in vivo unscheduled DNA synthesis (UDS) assay in the rat gastric mucosa: preliminary development. Carcinogenesis 1989; 10: $1425-8$.

5 Holt S, Howden CW. Omeprazole - overview and opinion. Dig Dis Sci 1991; 36: 385-93.

6 Maton PN. Drug-therapy - omeprazole. N Engl f Med 1991; 324: $965-75$.

7 Burlinson B, Morriss SH, Gatehouse DG, Tweats DJ. Genotoxicity of gastric acid inhibiting drugs. Lancet 1990; 335: 419-20.

8 Burlinson B, Morriss S, Gatehouse D, Tweats DJ. Comparative-studies on the gastric-acid inhibiting drugs (loxitidine, ranitidine, cimetidine and omeprazole) using the in ario stomach uds assay. Mutat Res 1991; 252: 184 
9 Anonymous. Omeprazole and genotoxicity. Lancet 1990; 335: 418.

10 Evans $\mathrm{HJ}$. Tests for genotoxicity - principles and findings in relation to omeprazole. Digestion 1990; 47: 45-8.

11 Pounder R. Omeprazole and genotoxicity [Letter]. Lancet 1990; 335: 612

12 Wright NA. DNA synthesis and genotoxicity. Digestion 1990; 47: $24-30$.

13 Ghatei MA, Uttenthal LO, Christofides ND, Bryant MG, Bloom SR. Molecular forms of human enteroglucagon in tissue and plasma: Plasma response to nutrient stimuli in health and disorder of the upper gastrointestinal tract. $7 \mathrm{Clin}$ Endocrinol Metab 1983; 57: 488-95.

14 Adrian TE, Ferri GI, Bacaresse-Hamilton AJ, Fussel HS, Polak JM, Bloom SR. Human distribution of a putative new gut hormone, Peptide YY. Gastroenterology 1985; 89: gut hor $1070-7$.

15 Bryant MG, Adrian TE, Gastrin. In: Bloom SR, Long RG, ed. Radioimmunoassay of gut regulatory peptides. London: W B Radioimmunoassay of

16 Altman DG. Practical statistics for medical research. London: Chapman and Hall, 1991.

17 Burlinson B, Morriss S, Gatehouse DG, Tweats DJ, Jackson MR. Uptake of tritiated-thymidine by cells of the rat gastricmucosa after exposure to loxtidine or omeprazole. Mutagenesis 1991; 6: 11-8.

18 Sachs G, Scott D, Reuben M. Omeprazole and the gastricmucosa. Digestion 1990; 47:35-8.

19 Ekman L, Bolcsfoldi G, Macdonald J, Nicols W. Reply. Lancet 1990; 335: 419-20.

20 Calam J, Goodlad RA, Lee CY, Ratcliffe B, Coates ME, Stamp GWH, et al. Achlorhydria-induced hypergastrinaemia: the $\mathrm{GWH}$, et al. Achlorhydria-induced hyperga
role of bacteria. Clin Sci 1991; 80: 281-4.

21 Deprez PH, Ghosh P, Goodlad RA, Lacey SL, Millership S, Playford RJ, et al. Hypergastrinaemia: a new mechanism. Lancet 1991; 338: 410-1.

22 Walsh JH. Role of gastrin as a trophic hormone. Digestion 1990; 47: 11-6.

23 Lewinski A, Rybicka I, Wajs E, Szkudlinski M, Pawlikowski $M$. Influence of pineal indoleamines on the mitotic-activity of gastric and colonic mucosa epithelial-cells in the rat interaction with omeprazole. 7 Pineal Res 1991; 10: 104-8.

24 Ryberg B, Tielemans Y, Axelson J, Carlsson E, Hakanson R, Mattson $\mathrm{H}$, et al. Gastrin stimulates the self-replication rate of enterochromaffinlike cells in the rat stomach. Effects of omeprazole, ranitidine, and gastrin-17 in intact and antrec-
tromized rats. Gastroenterology 1990; 99: 935-42.

25 Carlsson E, Havu N, Mattsson H, Ekman L. Gastrin and gastric enterochromaffin-like cell carcinoids in the rat. Digestion 1990; 47: 17-23.

26 Grey MR, Kingsnorth AN. Proliferative response of gastric body mucosa to short term administration of omeprazole. Gut 1991; 32: 581

27 Furihata C, Hirose K, Matsushima T. Genotoxicity and cell proliferative activity of omeprazole in rat stomach mucosa Mutat Res 1991; 262: 73-6.

28 Tielemans Y, Hakanson R, Sundler F, Willems G. Proliferation of enterochromaffinlike cells in omeprazole-treated hypergastrinemic rats. Gastroenterology 1989; 96: 723-9.

29 Havu N. Enterochromaffin-like cell carcinoids of gastric mucosa in rats after life-long inhibition of gastric secretion. Digestion 1986; 35: 42-55.

30 Berlin RG. Omeprazole - gastrin and gastric endocrine cell data from clinical-studies. Dig Dis Sci 1991; 36: 129-36.

31 D'Adda T, Pilato FP, Lazzaroni M, Robutti F, Bianchi PG, Bordi C. Ultrastructural morphometry of gastric endocrine cells before and after omeprazole. A study in the oxyntic mucosa of duodenal ulcer patients. Gastroenterology 1991; 100: $1563-70$

32 Cruetzfeldt W, Lamberts R, Stockmann F, Brunner G. Quantitative studies of gastric endocrine cells in patien receiving long-term treatment from omeprazole. Scand Gastroenterol Suppl 1989; 166: 122-8.

33 Helander HF, Simonsson M, Sundler F, Rutgersson K, Helander KG, Eriksson S. Histology of gastric biopsies from peptic ulcer patients before and after short-term treatment with omeprazole or H2-receptor antagonists. Virchows Arch [A] 1990; 417: 305-9.

34 Solcia E, Rindi G, Havu N, Elm G. Qualitative studies of gastric endocrine cells in patients treated long-term with gastric endocrine cells in patients treated long-term with

35 Eissel R, Roskopf B, Koop H, Adler G, Arnold R. Proliferation of endocrine cells in the rat stomach caused by druginduced achlorhydria. Gastroneterology 1991; 101: 70-6.

36 Wright NA, Alison MR. The biology of epithelial cell populations. Vol 2. Oxford: Oxford University Press, 1984

37 Larsson H, Fryklund J, Helander HF, Wallmark B. Partial pronase digestion of rat gastric mucosa isolates cells undergoing replicative DNA synthesis. Mutagenesis $1991 ; 6$ : 3-9.

38 Sachs $G$, Scott D. Cell digestion and genotoxicity assessment in gastric mucosa. Digestion 1990; 47: 31-4.

39 Wallmark B, Larsson H, Andersson K, Fryklund J, Helander HF. Tritiated thymidine incorporation into DNA in rat gastric mucosal cells. Digestion 1990; 47: 39-44.

40 Holt S, Powers RE, Howden CW. Antisecretory therapy and genotoxicity. Dig Dis Sci 1991; 36: 545-7. 